\title{
Scandinavian Component in Anglo-Saxon and Norman Identities
}

\section{A. A. Palamarchuk}

For citation: Palamarchuk A. A. Scandinavian Component in Anglo-Saxon and Norman Identities. Vestnik of Saint Petersburg University. History, 2020, vol. 65, issue 3, pp. 1016-1023.

https://doi.org/10.21638/11701/spbu02.2020.320

The article provides an analytical review of contemporary British historiography in the field of Anglo-Saxon and Norman ethnicity. On the one hand, modern scholars shift the focus on periphery and frontier regions of the kingdoms of Scotland and England and the Duchy of Normandy; on the other hand, the concept of "Atlantic archipelago" emphasizes the specificity of insular variant of ethno-political development. The phenomenon of "the Norman world", encompassing whole communities and territories inhabited by the Normans, is a fertile ground for realization of such "regional" approach. Both its strengths and limitations can be seen in the fundamental study "Heirs of the Vikings: History and Identity in Normandy and England, c. 950 - c. 1015" by Katherine Cross. She demonstrates that the denotation of the term "Norman" was not stable, and its interpretation was determined by the historical memory of a concrete region or community. Comparing two regions where, on the one hand, a complex ethnic landscape had been preserved by the $10^{\text {th }}-11^{\text {th }}$ centuries, and where, on the other hand, centralizing tendencies of the ambitious ruling dynasties had been developing, K. Cross seeks answers to the question "Why and how did Viking identity come to mean different things in England and Normandy?" The comparative approach to exploring Norman and English identities chosen by the author is realized exclusively on the basis of textual evidence: genealogies, ethnogenetic narratives, hagiography and charters. The analysis of "ethnic" discourse of the sources carried out by K. Cross is a vital, yet intermediate step towards a more fundamental debate.

Keywords: Anglo-Saxon, Norman, Viking, Identity, Ethnicity, Historiography.

\section{Скандинавский компонент в идентичности англосаксов и нормандцев}

\section{А.А. Паламарчук}

Для цитирования: Palamarchuk A. A. Scandinavian Component in Anglo-Saxon and Norman Identities // Вестник Санкт-Петербургского университета. История. 2020. Т. 65. Вып. 3. С. 1016-1023. https://doi.org/10.21638/11701/spbu02.2020.320

Anastasia A. Palamarchuk - Doctor in History, Associate Professor, St. Petersburg State University, 7-9, Universitetskaya nab., St. Petersburg, 199034, Russian Federation; a.palamarchuk@spbu.ru

Анастасия Андреевна Паламарчук - д-р ист. наук, доц., Санкт-Петербургский государственный университет, Российская Федерация, 199034, Санкт-Петербург, Университетская наб., 7-9; a.palamarchuk@spbu.ru

Financial support: St. Petersburg State University (travel grant "Territory and Power in Early Modern Antiquarian Discourse", Pure No. 42347703)

Статья подготовлена при финансовой поддержке СПбГУ (тревел-грант «Территория и власть в антикварном дискурсе раннего Нового времени», Pure No. 42347703)

(C) Санкт-Петербургский государственный университет, 2020 
Статья представляет собой критический анализ британской историографии в области изучения англосаксонских и нормандских идентичностей в Средние века. С одной стороны, для современных исследователей стал характерным отказ от «англоцентричности» и переключение внимания на периферийные и фронтирные регионы королевств Англии, Шотландии и герцогства Нормандского. С другой стороны, ситуацию определяет концепция «атлантического архипелага», подчеркнувшая специфику инсулярного варианта этнополитического развития. Результатом данного «регионального поворота» стала в том числе и существенная переоценка скандинавского фактора в формировании этнической карты Британии. Сам феномен «норманнского мира», «normannitas», охватывавшего отдельные общины и целые территории, заселенные потомками скандинавов, представляет собой благодатную почву для реализации «регионального» подхода. Преимущества и недостатки подобного подхода можно проследить на материале фундаментального исследования К. Кросс «Наследники викингов: история и идентичность в Нормандии и Англии, около 950-1015», посвященного изучению эволюции исходной скандинавской идентичности в двух исторически связанных регионах Нормандии и Англии. К.Кросс демонстрирует, что смысловое наполнение термина «norman» при этом не было устойчивым, а его интерпретация определялась исторической памятью конкретного региона или общины. Сопоставляя два региона, в которых в X-XI столетиях сохранялся сложный этнический ландшафт и развивались централизаторские амбиции правящих династий, К. Кросс пытается ответить на вопрос, как и почему исходная идентичность викингов приобрела разные значения в Англии и Нормандии. Однако компаративный подход к изучению нормандской и английской идентичностей реализован автором исследования исключительно на основе текстовых свидетельств (исторических нарративов, агиографического материала, хартий и т.д.). Проведенный К. Кросс анализ «этнического» словаря источников видится важным, но тем не менее промежуточным этапом в более фундаментальной дискуссии, требующей более пристального анализа потестарных и социальных структур в обоих регионах.

Ключевые слова: англосаксы, нормандцы, викинги, идентичность, этничность, историография.

The British historiography, especially the field of study of ethnicity, underwent considerable changes in the last years of the $20^{\text {th }}$ century. On the one hand, it was marked by an obvious tendency to reject "Anglo centricity" and shift the focus on periphery and frontier regions of the kingdoms of Scotland and England. On the other hand, the concept of "Atlantic archipelago" suggested by J. Morrill1", emphasizing the specificity of insular variant of ethno-political development, enabled to reconsider the diversity of ethno-cultural regions shaped over centuries as well as forms of legal and political structures which ensured the preservation of this diversity within the periods of the Middle Ages and Early Modern Time. The outcome of this "regional turn" was, among other things, a significant reassessment of the Scandinavian factor in shaping the ethnical map of Britain.

The phenomenon of "the Norman world", "normannitas" - encompassing whole communities and territories in Iceland and Greenland; on the Faroe, Shetland and Orkney Islands; in Ireland, Scotland and England; in the area of prospective Normandy; in southern Italy and Sicily; finally, on the eastern shore of the Baltic sea, and along the Volga and Dnieper trade routes — is a fertile ground for realization of the "regional" ap-

${ }^{1}$ Morrill J. The British Problem, 1534-1707 // State Formation in the Atlantic Archipelago / eds B. Bradshaw, J. Morrill. Basingstoke, 1996. P. 1-38; Kearney R. Britain and Ireland: Towards a Postnationalist Archipelago // The Edinburgh Review: New Writing and Critical Thought. 2000. No. 103. P.21-35. 
proach. "Transcultural heritage"2 of the Norman world, which had gradually included the territories of the British archipelago since the end of the $8^{\text {th }}$ century, bordering the local spectrum of Celtic and German traditions, stimulated the development of a vast array of ethno-cultural identities in Britain.

The fundamental study "Heirs of the Vikings: History and Identity in Normandy and England, c. $950-$ c. $1015^{\prime 3}$ by Katherine Cross, lecturer in Medieval History at the University of York, is devoted to exploration of the evolution of the initial "Viking identity" in two historically connected regions - Normandy and England.

In the introduction to her work, K. Cross defines one of the key paradoxes of the English medieval history: "After Edward the Confessor's death in 1066, three men claimed the English throne: William of Normandy, Harold Godwineson and Harald Hardrada (Haraldr Sigurðarson). Teachers and historians alike identify these claimants as Norman, English and Norwegian respectively" 4 . However, she continues, even a brief examination of their family trees shows that they all were descendants of the Scandinavians, and the contemporaries knew full well about it. Scandinavian descent was used as an effective political strategy and as a means of legitimation in the conflicts arising on the territory of the British archipelago in the $10^{\text {th }}-12^{\text {th }}$ centuries. "Each claimant to the English throne shaped his identity by either emphasizing or downplaying his Scandinavian heritage" ${ }^{\text {. At the same }}$ time, the denotation of the term "Norman" was not stable, and its interpretation was determined by the historical memory of a concrete region or community. Comparing two regions where, on the one hand, a complex ethnic landscape had been preserved by the $10^{\text {th }}-11^{\text {th }}$ centuries, and where, on the other hand, centralizing tendencies of the ambitious ruling dynasties had been developing, K. Cross seeks answers to the question "Why and how did Viking identity come to mean different things in England and Normandy?"

Each of the five chapters of the monograph sheds light on the main research question on the basis of a certain range of sources: genealogies, ethnogenetic narratives, hagiography and charters.

The first chapter "Genealogy: building a Viking Age Dynasty" is devoted to the analysis of the insular (Wessex) and continental (Frankish and Norman) models of constructing genealogy. Following D. N. Dumville ${ }^{6}$, the author points out that genealogies reflected the established identities and described the state of power structures typical of a concrete society. Meanwhile, the composition and the principles of constructing genealogies remained flexible so as to adequately respond to changes in social reality. K. Cross notes that the House of Wessex absolutely usurped the right to compile genealogies in West Saxon lands, while the dispersal of the royal power on the continent gave rise to the surge in aristocratic lineages. The descent from Rollo was still prestigious for the Norman rulers, although the family tree was made in such a way that it would meet the standards of the Frankish audience. West Saxon genealogies, also including distant Scandinavian ancestors

2 This term is used in the book "Norman Tradition and Transcultural Heritage: Exchange of Cultures in the 'Norman' Peripheries of Medieval Europe" / eds S. Burkhardt, Th. Foerster. New York; London, 2016.

3 Cross K. Heirs of the Vikings: History and Identity in Normandy and England, c. $950-$ c. 1015. York, 2018.

${ }^{4}$ Ibid. P. 1.

5 Ibid. P.2.

${ }^{6}$ Dumville D. N. Kingship, Genealogies and Regnal Lists // Early Medieval Kingship / eds P. H. Sawyer, J. N. Wood. Leeds, 1977. P.72-104. 
of the dynasty, attempted to stress equal importance of the "English" and "Scandinavian" components.

It should be noted that the author didn't consider a decisive factor for the comparative analysis of the "Wessex" and continental models of constructing genealogies. The factor in question is an active process of formation of feudal system and feudal law on the continent, including Normandy - and territorial ambitions of the continental aristocratic lineages connected with this process, in addition to the necessity of Dukes of Normandy to fit into post-Carolingian Frankish elites, which accounted for the importance of reflecting inter-dynastic marriages and female figures in the genealogies.

The second chapter - "Origin Myths: A People for the Dynasty" examines the issue of the evolution of identities not at the level of dynasty but at the level of gens - people as the community genetically linked to its ruling dynasty and its founder.

The Norman ethnogenetic myth is represented by a detailed analysis of "De moribus et actis primorum Normanniae ducum" by Dudo of St. Quentin - a pivotal text for the territorial and legal ambitions of the House of Normandy. The insular variant of inclusion of Scandinavian elements into the ethnogenetic myth is considered and exemplified by Chronicon Aethelweardi - a historical narrative compiled by ealdorman Aethelweard. Despite the fact that the authors were almost contemporaries (both texts were written at the end of the $10^{\text {th }}$ century, 20 years apart), Dudo and Aethelweard adopted contrasting approaches as far as the "Scandinavian" theme was concerned. According to K. Cross, Dudo was within the Frankish cultural tradition and conformed his narrative to the perceptions of Scandinavia and its inhabitants embedded in the continental literature. Aethelweard relied more on a living tradition, whose bearers his contemporaries-Danes remained ${ }^{7}$. The sources of the information and target audience were the key factors that, as K. Cross remarks, determined the content of "the Scandinavian myth" in each narrative. Even describing the two necessary elements of an ethnogenetic myth - migration and conversion to Christianity - each of the chroniclers drew on the system of symbols, poetics and structure which corresponded to the cultural language of the audience. However, of greater importance is the thesis, which is looked upon as secondary by K. Cross. The text by Aethelweard is based on integrating logic aimed at demonstrating genetic and religious commonality of all the subjects of contemporary rulers of Wessex. By contrast, Dudo's narrative follows the logic of separation, with the intention of showing the uniqueness and exclusiveness of the descendants of Rollo the Dane in post-Carolinian world ${ }^{8}$.

Two next chapters ("Hagiography 1: Ruin and Restoration" and "Hagiography II: Saintly Patronage") are united by examination of hagiography. It is difficult to overestimate scholars' unfailing interest in a vast array of Anglo-Saxon and Frankish hagiography as opposed to the history of local Norman cults, which is perceived as secondary. K. Cross suggests considering hagiography a powerful social means. While ethnogenetic narratives reflected the already established consensus, hagiographical accounts - to be precise, the whole complex of religious veneration (i. e., liturgical texts, relics, holidays recorded in ecclesiastical calendar, churches and chapel consecrated in honor of saints, places of memory etc.) were the active mechanisms of forming identities ${ }^{9}$.

${ }^{7}$ Cross K. Heirs of the Vikings... P. 83-84.

8 Ibid. P. 74-76.

9 For similar ideas about hagiography as the means of forming regional identities, see: Cohen J.J. Medieval Identity Machines. University of Minnesota, 2003; Campbell E. The Gift, Kinship and Community in Old French Hagiography. Cambridge, 2008. 
In both Norman and English hagiography (St. Edmund, St. Romanus, St. Audoenus) Scandinavians play a much lesser role than in historical narratives. Danes are pagans, the Scourge of God, who caused English kings to suffer martyrdom, whereas Norman monks seeking to avoid imminent death took the most precious possesions - relics and books and fled inland. The image of the Vikings was determined by their paganism, and, to a certain extent, was reduced to it.

Demonic cruelty and the origin of the Danes from the remote North are equated, whereas "dehumanization" of Scandinavian aggressors makes them similar to pagans persecutors of the Roman protomartyrs ${ }^{10}$. However, by the $10^{\text {th }}-11^{\text {th }}$ centuries insular saints had ceased to be associated with concrete political communities (Wessex, Northumberland) and became sacred figures significant for all English Christians. As in the case of ethnogenetic myths, insular hagiography demonstrates integrating logic representing Anglo-Saxons as Christians.

Hagiography in Normandy in the $11^{\text {th }}$ century - as well as the church in Normandy - was closely linked to political demands of the rulers. If Rollo and his Normans after the conversion become a new people, his descendants, in particular, Richard I of Normandy, assume the role of the restorer of the regional church, the new creator of the congregation returning the relics of saints to an appropriate setting. The protection of the whole gens of Normandy (as opposed to the "Frankish") and certain representatives of the dynasty (expressed in the scenes of Appearance of the saint to the ruler) was used as a strategic means of dynasty-building ${ }^{11}$.

The fifth, final chapter of "Charter Narratives: Normans, Northumbrians and Northmen" focuses on the analysis of the material which is not frequently involved in researches into ethnic history. It concerns Norman ducal charters and English royal diplomas. These texts compiled in royal and princely chancelleries enable to reconstruct the language of ethnicity and power, which was used if not by the King or Duke themselves but by their circle and representatives of the loyal elites.

In the charters by Richard I, II and III, in more than half of references, their title is supplemented by an identifier Normannorum, which, in K. Cross's opinion, can characterize them as "rulers of a single people"12. The collective term Normanni correlated not only with Scandinavians' descendants but also with the entity of inhabitants of the area of the principality - "Normannia". In Britain, the title Rex used in Aethelred's royal charters presupposed the supremacy of the monarch over the community of "angli" but not over a particular territory. Ethnic "Danes" are mentioned only as foreigners posing a threat; this ethnonym never refers to Scandinavian population of Northumberland. According to the author, documentary evidence in England and Normandy shows that in both regions there had been established consolidated power - of the King and Duke respectively whose object was ethnic community, not kinship or territorial commonality.

Undoubtedly, K.Cross's book can be regarded as a significant contribution to the study of the phenomenon of identities during Early Middle Ages. However, it should be noted that the comparative approach to exploring Norman and English identities chosen by the author is realized exclusively on the basis of textual evidence. The reality of Anglo-Norman world is reduced to the world of texts, while factual, social, dynastic and

${ }^{10}$ Cross K. Heirs of the Vikings... P. 93.

11 Ibid. P. 150-151.

12 Ibid. P. 166. 
political contexts determining the mere fact of creation of texts and their content are left outside the scope of research. It is obvious that this approach has been adopted deliberatively: the author admits that "the meaning of Viking identity developed differently in England and Normandy because of the specifics of those local contexts, and the actions of their inhabitants, as they attempted to forge new societies from mixed population"13. K. Cross cannot be criticized for incomplete coverage of the theme. Throughout the whole book, she maintains impeccable logic and methodological precision, therefore the "microcosm" of her research seems harmonious and thorough.

Nonetheless, the explanation of the reasons why the descendants of Vikings in two European regions over the course of a century and a half had differed so appreciably in interpreting their own identities, can be extended both by going beyond the narratives and by shifting the focus of their analysis.

Presenting the medieval worldview of the middle of the $11^{\text {th }}$ century, K. Cross widely uses the term "people" (it is more noticeable by the end of the fifth chapter ${ }^{14}$ ). As terminus technicus, it is absolutely acceptable; however, applying the term "people", which presupposes a certain level of ethic development, to the reality of Northern Europe of the Middle Ages is generally problematic. The period in question was the time of active formation of feudal landscape in Europe. Feudal rule until the end of medieval epoch remained personalized by its nature; the boundaries of feudal tenures over the course of centuries had hindered territorial and ethnic integration. To a certain extent, ethnic factor as a means of organizing reality was inferior to personal, social and, obviously, legal ones. With regard to this, the issue of interpreting terminology of the Norman charters is becoming controversial: the author rightly points out that the Duke's charters and diplomas reflect the reality of jurisdictions and the transfer of rights; they record statuses, titles and posts (cubicularius, procurator, cancellarius etc.) - administrative terms. These same texts, according to the author, contain references to "united Normandy" 15 , however, admitting the internal integrity of each document, isn't it better to perceive this concept not as ethnic, but as, first and foremost, legal or administrative-legal? In this context, the standpoint of Fraser McNair ${ }^{16}$ seems more convincing: he believes that "Norman" defined political, not ethnic, identity for Dudo as well as for later historians.

The analysis of "ethnic" discourse of the sources carried out by K. Cross is a vital, yet intermediate step towards a more fundamental debate.

The first question arising upon reading the book is that of the reflection in narratives of the model of leadership in Normandy. In 2002, D. Crouch ${ }^{17}$ comprehensively reconstructed the process of replacement and assimilation of elites during the rule of William Longsword, presenting this process as politically determined. The transition from chiefdom to lordship was described as a consequence of a long chain of situational decisions aimed at ensuring the stability and authority of the dynasty being under the constant pressure from neighboring Franks and Bretons.

13 Ibid. P. 214.

${ }^{14}$ For the most powerful statements, see: Ibid. P. 167, 193.

15 Ibid. P. 157.

${ }^{16}$ McNair F. The politics of being Norman in the reign of Richard the Fearless, Duke of Normandy (r. 942-996) // Early Medieval Europe. 2015. No.23 (3). P. 308-328.

17 Crouch D. The Normans: The History of a Dynasty. New York, 2002. See especially at p. 14-27. 
However, D.Crouch's approach is in stark contrast to that of K. Cross: if the latter ignores factual and social contexts, the former takes no notice of the narratives. It appears that the balance between both strategies would yield impressive results. A logical continuation of the research might be comparison between the dynamics of the described "ethnic" vocabulary and the dynamics of ethnic and social changes in Normandy. The emergence of the concept "normanni" and identificator "normannorum" in the 1020s, and later until the reign of William the Bastard, ran parallel to the formation of feudal dynasties with the potential of challenging the kin of Duke; the issue of the relevance of integrating ethnic identificator within this context remains open. Alternatively, the above-mentioned interpretation of normannitas as a political collective identificator seems more appropriate.

Another interesting aspect worth exploring is the extent to which the system of relationships between the Duke and his vassals, traditionally characterized as reduced "Norman model of feudalism", comprised components of continuity with Scandinavian system of military leadership ${ }^{18}$. The debate about Norman feudalism covered by M.Cinball ${ }^{19}$ in detail mostly elucidated such themes as the issues of developed Norman feudal system of the middle of the $11^{\text {th }}$ century and later, or mechanisms of adaptation of Norman model of seigneurial relationships to the British Isles. An earlier stage of the evolution of chiefdom of Scandinavian type towards not only Christian rule (as described by K.Cross), but also towards the feudal dominance remained outside the scope of the researchers, predominantly due to the absence of documented sources. Was the Scandinavian heritage a decisive factor which determined the peculiarity of Norman society in comparison with Frankish lands or insular world? Given the thesis about a rapid assimilation of conquerors and dilution of initial Scandinavian community of Rollo's associates by the $11^{\text {th }}$ century, what prevented the "Frankish" model of feudal hierarchy from being established on the territory of Normandy? Finally, was the perception of the ownership of the conquered land by the military leader, which hadn't lost its relevance for the English constitutional ideas after 1066 and up until the $17^{\text {th }}$ century ${ }^{20}$, genetically connected with the typical Scandinavian interpretation of distribution of rights to military trophies?

The book "Heirs of the Vikings" can be a fantastic springboard for further consideration.

\section{References}

Campbell E. The Gift, Kinship and Community in Old French Hagiography. Cambridge, D. S. Brewes, 2008, $276 \mathrm{p}$.

Cinball M. Feudalism and Lordship. A Companion to the Anglo-Norman World. Woodbridge, The Boydell Press, 2003, pp. 124-134.

Cohen J. J. Medieval Identity Machines. University of Minnesota Press, 2003. 336 p.

Cross K. Heirs of the Vikings: History and Identity in Normandy and England, c.950-c.1015. York, York Medieval Press, 2018, 262 p.

Crouch D. The Normans: The History of a Dynasty. New York, Hambledon continuum, 2002, 378 p.

18 Fyodorov S. E., Palamarchuk A. A. Srednevekovaia Schotlandiia. St. Petersburg, 2014; Fyodorov S. E. Identitarnye protsessy v srednevekovom Uel'se: terminologiia, diskursy i situatsiia bilingvizma (proizvodnye ot wēalas opredeleniia) // Dialog so vremenem. 2018. No.62. P.48-61.

19 Cinball M. Feudalism and Lordship // A Companion to the Anglo-Norman World / eds C. HarperBill, E. van Houts. Woodbridge, 2003. P. 124-134.

${ }_{20}$ Palamarchuk A.A. Kompozitarnaia monarkhiia i pravovoi polimorfizm v rannestiuartovskoi Anglii: k postanovke problemy // Istoriia. Elektronnyi nauchnyi zhurnal. 2018. No. 1 (65). 
Dumville D. N. Kingship, Genealogies and Regnal Lists. Early Medieval Kingship. Leeds, University of Leeds, 1977, pp. 72-104.

Fyodorov S. E., Palamarchuk A. A. Medieval Scotland. St. Petersburg, Aleteia Publ., 2014, 352 p. (In Russian). Fyodorov S.E. The Identity processes in Medieval Wales. Terminology, Discourses, and Context of Bilingualism (wēalas-based nomenclature). Dialog so vremenem, 2018, no. 62, pp. 48-61. (In Russian)

Kearney R. Britain and Ireland: Towards a Postnationalist Archipelago. The Edinburgh Review: New Writing and Critical Thought, 2000, no. 103, pp.21-35.

McNair F. The politics of being Norman in the reign of Richard the Fearless, Duke of Normandy (r. 942996). Early Medieval Europe, 2015, no. 23 (3), pp.308-328.

Morrill J. The British Problem, 1534-1707. State Formation in the Atlantic Archipelago. Basingstoke, MacMillan, 1996, pp.1-38.

Palamarchuk A. A. Composite Monarchy and Legal Polymorphism in Early Stuart England: a Problem Statement. Istoriia. Elektronnyi nauchnyi zhurnal, 2018, no. 1 (65). (In Russian)

Статья поступила в редакцию 6 июня 2019 г. Рекомендована в печать 8 июня 2020 г.

Received: June 6, 2019

Accepted: June 8, 2020 